\title{
PENGARUH KEMUDAHAN PENGGUNAAN DAN KEAMANAN TERHADAP NIAT PENGGUNAAN DAN DAMPAKNYA PADA NIAT MEREKOMENDASIKAN SISTEM M-PAYMENT DI MASA PANDEMI COVID-19
}

\author{
Anggit Yoebrilianti, Nurhayani \\ Fakultas Ekonomi dan Bisnis, Universitas Serang Raya \\ Email korespondensi: anggit@unsera.ac.id
}

\begin{abstract}
Abstrak.
Penelitian ini bertujuan untuk menganalisis dan menguji kemudahan penggunaan dan faktor keamanan terhadap niat penggunaan dan menguji dampaknya terhadap niat merekomendasikan penggunaan layanan $m$ payment di Indonesia khususnya pada Kota Serang, Provinsi Banten. Penelitian ini menggunakan pendekatan kuantitatif. Populasi penelitian ini adalah seluruh pengguna layanan pembayaran m-payment di Kota Serang yang menggunakan aplikasi Go-Pay, Ovo dan Dana. Sampel penelitian diambil dengan menggunakan teknik purposive sampling. Pengumpulan data dilakukan dengan melakukan penyebaran kuesioner secara daring (online) sehingga didapatkan data sebanyak 190 responden. Data diolah dengan menggunakan teknik analisis partial leats square structural equation modeling (PLS-SEM). Hasil penelitian ini menunjukkan bahwa kemudahan penggunaan dan keamanan berpengaruh positif dan signifikan terhadap niat penggunaan layana $m$ payment. Penelitian ini juga menemukan pengaruh yang signifikan dari niat penggunaan terhadap niat merekomendasikan layana m-payment.
\end{abstract}

Kata kunci: Kemudahan penggunaan, keamanan, niat penggunaan, niat merekomendasikan, m-payment.

\begin{abstract}
.
This study aims to analyze and examinet impact of ease of use and security factor on the intention to use, and examine its impact on intention to recommend in using m-payment in Serang City, Banten Province. This study uses a quantitative approach. The population of this study were all users of m-payment in Serang City that using Go-Pay, Ovo and Dana applications. Research sample was taken using purposive sampling technique. The data was collected by distributing questionnaires online so that 190 respondents were obtained. Data were analyzed using partial leats square structural equation modeling (PLS-SEM). This study found that ease of use and security have a positive and significant effect on the intention to use the m-payment service. This study also found that intention to use has a significant effect on intention to recommend m-payment service.
\end{abstract}

Keywords: ease of use, security, intention to use, intention to recommend, m-payment.

\section{PENDAHULUAN}

Teknologi internet berkembang sangat cepat dalam dua dekade terakhir. Hal ini didukung oleh pertumbuhan pengguna internet Indonesia yang sangat besar yaitu 171,17 juta orang di tahun 2018, dimana lebih dari $65 \%$ orang Indonesia yang menggunakan teknologi internet. Pertumbuhan tersebut terus mengalami peningkatan sebesar $10,12 \%$ atau lebih dati 20 juta orang pengguna internet di Indonesia setiap tahunnya (APJII, 2018). Perkembangan dan pertumbuhan tersebut telah mengubah perilaku masyarakat Indonesia dalam memanfaatkan teknologi internet yang terfokus pada kegiatan ekonomi (APJII, 2017). Persentase pemanfaat internet pada kegiatan ekonomi dapat dilihat pada gambar di bawah ini. 


\section{EKOMBIS Sains}

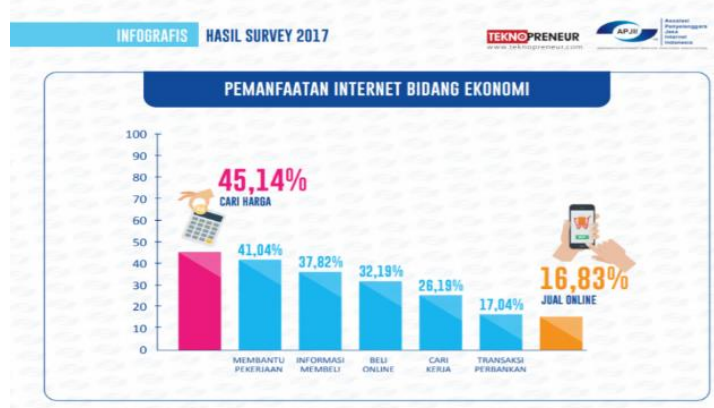

Gambar 1. Pemanfaatan Internet Bidang Ekonomi

Sumber: APJII 2017

Data di atas menunjukkan bahwa pengguna internet di Indonesia mengalami perubahan perilaku dalam melakukan transaksi jual beli dari offline menjadi online. Perubahan tersebut juga harus didukung dari aspek keuangan agar transaksi jual beli menjadi lebih efektif. Fakta di atas direspon dengan sangat baik oleh para pelaku bisnis di bidang keuangan, dimana muncul banyak perusahaan yang menyediakan layanan keuangan dengan menggunakan aplikasi mobile yang dikenal dengan m-payment sebagai sarana pembayaran digital dalam dalam 5 tahun terakhir. Sistem tersebut dapat diakses dengan mudah dan digunakan dimana saja. MDI Ventures dan Mandiri Sekuritas Research pada tahuan 2019 menemukan bahwa sepanjang tahun 2013-2018 penyedia layanan m-payment bertambah dengan sangat pesat meskipun pertama kali keluarnya pada tahun 2007. Hal ini terjadi karena perkembangan teknologi m-payment sangat bergantung pada perkembangan teknologi internet mobile device dan jaringan mobile dan pertumbuhan pihakpihak pendukung (Johnson et al., 2018). Tanpa adanya perkembangan yang cukup signifikan dari beberapa faktor tersebut sistem m-payment tidak bisa dilakukan di mana saja dan kapan saja.

Menurut Liébana-Cabanillas et al., (2017b) m-payment merupakan sarana penyelesaian transaksi keuangan atau pembelian antara individu atau entitas lain menggunakan alat yang cepat, nyaman, mudah, dan aman di mana saja dari perangkat seluler. Pendapat mereka menunjukkan bahwa m-payment memiliki fungsi yang sangat baik dalam memudahkan proses transaksi keuangan khususnya dalam hal pembayaran. M-payment menawarkan sistem pembayaran yang efektif bagi para penjual dari berbagai macam jenis produk dan layanan (Mallat, 2008).

Penggunaan m-payment di Indonesia masih terbilang baru sehingga masih membutuhkan waktu bagi masyarakat Indonesia untuk memutuskan untuk menggunakannya atau tidak. Lebih jauh, layanan m-payment mayoritas lebih banyak digunakan di daerah perkotaan karena masyarakat perkotaan lebih mudah menerima edukasi tentang penggunaan $m$ payment dibandingkan masyarakat pedesaan. Hal ini disebabkan karena perkembangan teknologi internet juga masih terpusat di daerah perkotaan sehingga pertumbuhan penggunaan pembayaran digital masih terfokus pada daerah tertentu. Namun, perilaku transaksi secara cashless atau non tunai juga mulai berkembangan dan digunakan oleh konsumen daerah pedesaan khususnya peritel. iPrice mengklaim bahwa layanan layanan m-payment semakin populer seiring meningkatnya pemakaian smartphone hingga $70 \%$ dalam lima tahun terakhir di Indonesia.

Beberapa peneliti terdahulu meyakini faktor manfaat menjadi pendorong utama seseorang untuk mau atau memiliki niat untuk menggunakan layanan m-payment. Salah satunya adalah kemudahan penggunaan (Johnson et al., 2018; Phonthanukitithaworn et al., 2016), dimana niat seseorang untuk menggunakan $m$ payment tergantung pada manfaat yang diberikan layanan tersebut yaitu kemudahan menggunakan sistem pembayaran tersebut. Sayangnya, penelitian yang dilakukan Liébana-Cabanillas et al., (2018) pada pengguna m-payment dari mahasiswa di 
Spanyol menemukan hasil yang berbeda yaitu kemudahan penggunaan tidak memiliki pengaruh yang signifikan terhadap niat penggunaanya. Hasil ini menunjukkan bahwa pengaruh kemudahan penggunaan terhadap niat penggunaan m-payment masih tidak konsisten.

Faktor lain yang dapat memunculkan niat seseorang menggunakan m-payment adalah keamanan (Oliveira et al., 2016; Liébana-Cabanillas et al., 2017a). Keamanan menjadi perhatian utama pengguna m-payment karena kurangnya ketika mereka merasa tidak percaya terhadap teknologi baru dan kemungkinan ada risiko ketika menggunakannya akan membuat mereka punya kecenderungan untuk tidak mau mengadopsi dan menggunakan $m$ payment (Liébana-Cabanillas et al., 2017b). Menurut Metemba dan Li (2018) hal ini terjadi karena konsumen online secara alamiah cenderung akan menggunakan sistem pembayaran yang mampu memastikan integritas, kerahasian dan yang tidak mengakui transaksi mereka. Sayangnya, penelitian terkait aspek keamanan sebagai faktor penentu seseorang untuk menggunakan layanan m-payment masih sangat terbatas, sehingga dibutuhkan penelitian lebih lanjut untuk mengetahui dampak aspek keamanan terhadap niat penggunaan m-payment di Indonesia.

Secara umum, beberapa penelitian terdahulu menunjukkan bahwa pengaruh sosial dari orang-orang terdekat individu memainkan peran penting sebagai pendorong untuk mengadopsi suatu teknologi. Ikhsan dan Sunaryo (2020), Chaouali et al., (2016) dan Hsu \& Lin (2016) menemukan bahwa individu sangat terpengaruh oleh informasi-informasi sosial dari lingkungan sekitar. Sayangnya, belum banyak penelitian yang membahas apakah individu yang pernah menggunakan suatu teknologi benar-benar memberikan rekomendasi terhadap orang lain dalam menggunakan suatu teknologi.
Berdasarkan fenomena yang telah dijelaskan di atas, peneliti bertujuan untuk mengetahui dan menguji keterkaitan antara variabel kemudahan penggunaan, keamanan, niat penggunaan dan niat merekomendasikan konsumen terdahap layanan m-payment di Kota Serang.

\section{KAJIAN PUSTAKA}

\section{Kemudahan Penggunaan}

Bailey et al., (2017) mendefinisikan kemudahan penggunaan merupakan persepsi konsumen tentang upaya yang harus dikeluarkan untuk menggunakan $m$ payment dan sejauh mana teknologi tersebut dapat dimengerti atau tidak. Dengan begitu, terlihat bahwa semakin mudah teknologi tersebut digunakan akan semakin mudah upaya yang harus mereka keluarkan dan akan memberikan dampak positif bagi kinerja seseorang ketika menggunakannya. Hal ini terjadi karena kemudahan penggunaan juga menekankan manfaat dari suatu teknologi tersebut (Davis, 1989; Davis et al., 1989). Oleh karena itu, beberapa peneliti terdahulu berpendapat bahwa seseorang akan mengadopsi suatu teknologi jika mereka merasa bahwa teknologi tersebut mudah untuk digunakan dan tidak merepotkan (Zhu et al., 2012). Aslam et al., (2017) mengatakan bahwa terdapat empat indikator utama yang mencerminkan kemudahan penggunanan m-payment yaitu m-payment mudah digunakan, penggunaan m-payment jelas dan mudah dimengerti, mudah menjadi mahir dalam menggunakan m-payment, dan mudah memahami setiap tahapan penggunaan m-payment

\section{Keamanan}

Keamanan adalah seperangkat prosedur dan program untuk memverifikasi sumber informasi dan menjamin integritas dan privasi dari informasi tersebut (Tsiakis dan Sthephanides, 2005). Hal ini menandakan bahwa keamanan menjadi salah satu 
mekanisme penting yang digunakan untuk memastikan bahwa suatu teknologi dapat dipercaya dalam menjaga dan menyimpan informasi pribadi pengguna teknologi tersebut. Karena mayoritas konsumen cenderung merasa bahwa ada risiko atau kemungkinan menderi kerugian ketika menggunakan suatu teknologi sehingga masalah keamanan menjadi hal yang dapat menghambat seseorang untuk mengadopasi teknologi khususnya m-payment (LiébanaCabanillas et al., (2017b). Oleh karena itu, konsumen akan mengadopsi layanan $m$ payment sebagai sarana transaksi keuangan hanya jika teknologi m-payment bisa membuat mereka merasa aman (Oliveira et al., 2016). Menurut Zhou (2011) terdapat tiga indikator penting dari segi keamanan dalam menggunakan layanan m-payment yaitu memilki langkah-langkah untuk melindungi layanan m-payment, memilki kemampuan memverikasi pengguna yang sah dan dapat memastikan keamanan informasi pembayaran.

\section{Niat Penggunaan}

Menurut Jogiyanto (2007) niat penggunaan adalah keinginan seseorang untuk melakukan suatu perilaku. Definisi tersebut menunjukkan bahwa niat akan mengarah kepada perilaku tertentu yang mereka inginkan. Misal, niat invidu terhadap suatu teknologi. Jika individu niat untuk menggunakan teknologi tersebut, dia akan memiliki keinginan yang tinggi untuk menggunakannya. Hal ini sejalan dengan pandapat Davis et al., (1989) yang mengatakan bahwa niat menggunakan suatu teknologi adalah tingkat seberapa kuat seseorang ingin atau memiliki niat untuk menggunakan suatu teknologi. Oleh karena itu, niat merupakan kecenderungan perilaku seseorang untuk mulai menggunakan atau tepat menggunakan suatu teknologi. Menurut Davis et al., (1989) ada tiga indikator utama yang dapat menggambarkan niat seseorang untuk menggunakan suatu teknologi yaitu keinginan untuk menggunakan (intend to continue using), berencana untuk menggunakan (plan to continue to use) dan selalu berusaha menggunakan (will always try to use).

\section{Pengaruh Kemudahan Penggunaan Terhadap Niat Penggunaan M-Payment}

Persepsi kemudahan menggunakan menggambarkan kondisi dimana individu mudah melakukan transaksi keuangan tanpa mengeluarkan banyak usaha. Kemudahan tersebut terlihat dari fitur-fitur yang disediakan oleh sistem m-payment seperti mudah digunakan, mudah dipelajari, jelas dan mudah dipahami cara penggunaannya. Kemudahan tersebut menjadi daya tarik bagi individu untuk menggunakannya karena tidak membutuhkan banyak usaha untuk menggunakannya. Hal ini didukung oleh hasil peneliti terdahulu yang menemukan bahwa kemudahan penggunaan memiliki pengaruh positif dan signifikan terhadap niat penggunaan aplikasi mobile pada layanan $m$ payment (Johnson et al., 2018; Phonthanukitithaworn et al., 2016; Ikhsan dan Sunaryo, 2020).

\section{Pengaruh Keamanan Terhadap Niat Penggunaan M-Payment}

Keamanan merupakan mekanisme untuk menghimpun transaksi keuangan seseorang secara online dengan aman dan menjaga kerahasiaan informasi pribadi mereka khususnya dalam penggunaan $m$ payment. Hal ini disebabkan karena secara natural konsumen online akan lebih memilih sistem pembayaran yang memastikan integritas, kerahasian dan yang tidak mengakui transaksi mereka (Matemba dan Li, 2018). Oleh karena itu, peneliti berpendapat bahwa keamanan merupakan salah satu faktor penting yang menentukan seseorang mengadopsi m-payment atau tidak. Hal ini didukung oleh penelitian sebelumnya yang menunjukkan bahwa keamanan memiliki pengaruh yang positif dan signifikan terhadap niat penggunaan 
suatu sistem m-Payment (Oliveira et al., 2016).

\section{Pengaruh Niat Penggunaan Terhadap Niat Merekomendasikan M-Payment}

Niat penggunaan merupakan suatu keinginan seseorang untuk melakukan suatu bentuk tindakan. Dengan begitu, segala bentuk tindakan yang dilakukan seseorang akan sangat bergantung pada niat yang dimilikinya. Hal ini disebabkan karena banyak orang terpengaruh oleh informasi sosial yang mereka dapatkan dari orangorang terdekat baik secara langsung ataupun melalui media sosial (Ikhsan dan Sunaryo, 2020; Oliveira et al., 2016). Oleh karena itu, peneliti berpendapat bahwa niat penggunaan memaikan peran penting sebagai faktor pendorong seseorang untuk merekomendasikan penggunaan suatu teknologi khususnya m-payment kepada orang lain. Hal ini didukung oleh penelitian sebelumnya yang menunjukkan bahwa niat penggunaan memiliki pengaruh yang positif dan signifikan terhadap niat merekomendasikan suatu sistem $m$-Payment (Oliveira et al., 2016).

\section{Hipotesis Penelitian}

Berdasarkan penjelasan di atas peneliti merumuskan hipotesis sebagai berikut:

$\mathrm{H1}$ : Kemudahan penggunaan berpengaruh positif terhadap niat penggunaan M-Payment H2: Keamanan berpengaruh positif terhadap niat penggunaan $M$-Payment

H3: Niat penggunaan berpengaruh positif terhadap niat merekomendasikan M-Payment

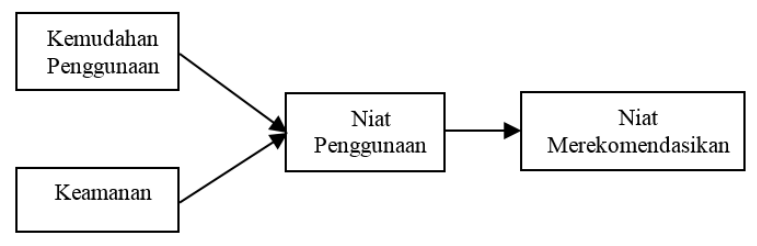

Gambar 2. Model Penelitian

\section{METODE PENELITIAN}

Penelitian ini dilakukan dengan menggunakan pendekatan kuantitatif yang bertujuan untuk menguji teori-teori tertentu dengan cara meneliti hubungan antarvariabel (Noor, 2017). Oleh karena itu, penelitian ini bertujuan untuk menguji pengaruh kemudahan penggunaan dan keamanan terhadap niat penggunaan, serta menguji dampaknya sebagai faktor penentu konsumen untuk merekomendasikan layanan m-payment.

Populasi dalam penelitian ini adalah seluruh pengguna layanan pembayaran $\mathrm{m}$ payment di Kota Serang yang menggunakan aplikasi Go-Pay, Ovo dan Dana. Sampel penelitian ini diambil dengan teknik purposive sampling dengan beberapa kriteria yaitu individu yang pernah menggunakan layanan m-payment dalam jangka waktu tiga bulan terakhir dan menggunakannya di lokasi yang menjadi wilayah sampel yaitu Kota Serang. Data penelitian ini dikumpulkan dengan menggunakan metode survei dalam jaringan (online). Kuesioner dalam penelitian ini dibuat dalam format google document secara online dan didistribusikan kepada pengguna layanan m-payment yang berada di Kota Serang. Item-item pernyataan yang disampaikan dalam kuesioner berjumlah 12 item pernyataan yang masing-masing terdiri atas empat untuk variabel kemudahan penggunaan, tiga untuk variabel keamanan, tiga untuk variabel niat penggunaan dan dua untuk variabel niat merekomendasikan. Semua item pengukuran tersebut diadaptasi dari penelitian sebelumnya yang telah melakukan penelitian sejenis. Proses pengumpulan data dilakukan selama 7 hari yaitu dari tanggal 1 April s/d 7 April 2021. Penelitian ini menggunakan analisis structural equation model (SEM) yang berbasis varians yaitu partial least square (SEM-PLS) dengan software WarpPLS 5.0. 


\section{HASIL DAN PEMBAHASAN}

\section{Deskripsi Responden}

Responden pada penelitian ini sangat bervariasi baik dari segi jenis kelamin, usia, pendidikan dan layanan m-payment yang digunakan. Dari 190 responden mayoritas didominasi oleh wanita yaitu sebanyak 108 $(56,8 \%)$ dan diikuti responden laki-laki sebanyak 82 (43,2\%). Berdasarkan usia, responden usia 21-35 Tahun sebanyak 152 (80\%), dibawah 20 tahun sebanyak $28(14,7 \%)$ dan yang berusia diatas 35 tahun sebanyak 10 $(5,3)$. Berdasarkan tingkat pendidikan, responden dalam penelitian ini didominasi oleh lulusan S1 dan SMA/SMK, kemudian disusul responden dengan tingkat pendidikan Diploma, S2 \& S3 dan SD/SMP. Berdasarkan jenis layanan m-payment responden dalam penelitian ini didominasi oleh pengguna Gopay sebanyak $134(70,5)$, pengguna OVO sebanyak $41(21,6 \%)$ dan pengguna DANA sebanyak 15 (7,9\%). Hasil persentase secara keseluruhan karateristik responden tersebut dapat dicermati pada Tabel 1.

Tabel 1. Karateristik Responden

\begin{tabular}{lllcc}
\hline Karateristik & & Item & Jumlah & $\begin{array}{c}\text { Persentase } \\
(\%)\end{array}$ \\
\hline Jenis kelamin & a. & Laki-laki & 82 & 43,2 \\
& b. & Wanita & 108 & 56,8 \\
Usia & a. & $\leq$ 20 Tahun & 28 & 14,7 \\
responden & b. & 21-35 Tahun & 152 & 80 \\
Pendidikan & c. & a. 35 tahun & 10 & 5,3 \\
terakhir & b. & SMA/SMP & 3 & 1,6 \\
& c. & Diploma/setara & 70 & 36,8 \\
& d. & S1/setara & 99 & 6,3 \\
Mobile & e. & S2 \& S3 & 6 & 32,1 \\
payment & a. & Gopay & 134 & 70,5 \\
& b. & Ovo & 41 & 21,6 \\
& c. & DANA & 15 & 7,9 \\
\hline
\end{tabular}

\section{Model Pengukuran}

Uji validitas dilakukan dengan melihat validitas konvergen dan diskriminan. Validitas konvergen diuji menggunakan nilai loading dari setiap item pernyataan pada variabel penelitian. Item pengukuran dapat dikatakan baik dan tidak memiliki masalah dengan validitas konvergen jika nilai loading-nya lebih besar dari 0,5 dan mengelompok ke masing-masing faktor atau variabel yang telah disebutkan pada penjelasan sebelumnya. Secara keseluruhan hasil pengujian menunjukkan bahwa semua item pengukuran dari variabel persepsi kegunaan, persepsi kemudahan menggunakan, sikap dan niat memiliki nilai faktor loading yang lebih besar dari 0,5. Oleh karena itu, dapat dikatakan bahwa indikator pada masing-masing variabel memiliki tingkat akurasi yang tinggi karena memiliki nilai muatan faktor indikator reflektif yang $\geq 0,5$. Lebih lengkapnya hasil pengujian validitas konvergen dapat dilihat pada Tabel 2.

Tabel 2. Hasil Pengujian Validitas dan reliabilitas

\begin{tabular}{|c|c|c|c|c|c|c|}
\hline Variabel & Item & $\begin{array}{c}\text { Nilai } \\
\text { Loading }\end{array}$ & AVE & SRAVE & $\begin{array}{c}\text { Conbach } \\
\text { alpha }\end{array}$ & $\begin{array}{l}\text { Composite } \\
\text { Reliability }\end{array}$ \\
\hline & KEP1 & 0.841 & \multirow{4}{*}{0.734} & \multirow{4}{*}{0.857} & \multirow{4}{*}{0.879} & \multirow{4}{*}{0.917} \\
\hline Kemudahan & KEP2 & 0.879 & & & & \\
\hline Penggunaan & KEP3 & 0.813 & & & & \\
\hline \multirow{4}{*}{ Keamanan } & KEP4 & 0.891 & & & & \\
\hline & KEA1 & 0.837 & \multirow{3}{*}{0.733} & \multirow{3}{*}{0.856} & \multirow{3}{*}{0.817} & \multirow{3}{*}{0.892} \\
\hline & KEA2 & 0.839 & & & & \\
\hline & KEA3 & 0.891 & & & & \\
\hline \multirow{3}{*}{$\begin{array}{c}\text { Niat } \\
\text { Penggunaan }\end{array}$} & NP1 & 0.848 & \multirow{3}{*}{0.762} & \multirow{3}{*}{0.873} & \multirow{3}{*}{0.843} & \multirow{3}{*}{0.905} \\
\hline & NP2 & 0.888 & & & & \\
\hline & NP3 & 0.882 & & & & \\
\hline \multirow{2}{*}{$\begin{array}{c}\text { Niat } \\
\text { merekomend } \\
\text { asikan } \\
\end{array}$} & NM1 & 0.948 & \multirow[b]{2}{*}{0.898} & \multirow[b]{2}{*}{0.948} & \multirow[b]{2}{*}{0.887} & \multirow[b]{2}{*}{0.946} \\
\hline & NM2 & 0.948 & & & & \\
\hline
\end{tabular}

Pada penelitian ini, peneliti juga menggunakan nilai AVE dalam menguji validitas konvergen, dimana nilainya harus lebih besar dari 0,5 (Hair et al., 2014). Nilai AVE di atas 0,5 akan menunjukkan bahwa suatu variabel tidak akan masuk variabel lain karena hanya akan masuk ke variabel yang sebenarnya. Tabel 2 menunjukkan bahwa semua variabel dalam penelitian ini memiliki nilai AVE di atas 0,5 yang secara berturut-turut sebesar 0.734, 0.733, 0.762 dan 0.898 . Hal ini menunjukkan bahwa semua variabel pada penelitian ini berbeda antara satu variabel dengan variabel lainnya. Dengan begitu, dapat dikatakan semua variabel dalam penelitian ini memenuhi kriteria uji validitas konvergen yang baik.

Validitas diskriminan dilakukan dengan membandingkan nilai akar AVE (SRAVE) dari setiap variabel dengan korelasi antar variabel dalam penelitian ini (Hair et al., 2014). Model pengukuran dapat dikatakan memiliki validitas diskriminan yang baik jika nilai akar AVE dari setiap variabel lebih besar dari pada korelasi antar variabel yang satu dengan yang lainnya. Tabel 2 dan 3 menunjukkan bahwa setiap variabel memiliki nilai akar AVE yang lebih besar dari pada nilai korelasi antar variabel. Lebih lengkapnya hasil pengujian validitas diskriminan dapat dilihat pada tabel di bawah ini.

Tabel 3. Korelasi Antar Variabel

\begin{tabular}{lllll}
\hline Variabel & KEP & KEA & NP & NM \\
\hline
\end{tabular}




\section{EKOMBIS Sains}

\begin{tabular}{ccccc}
\hline Kemudahan & 1 & & & \\
Penggunaan & & & & \\
Keamanan & $0.532^{\mathrm{a}}$ & 1 & & \\
Niat Penggunaan & $0.636^{\mathrm{a}}$ & $0.585^{\mathrm{a}}$ & 1 & \\
$\begin{array}{c}\text { Niat } \\
\text { merekomendasikan }\end{array}$ & 0.114 & 0.162 & $0.175^{\mathrm{b}}$ & 1 \\
\hline Catatan: ${ }^{\mathrm{a}} p$-value $<0,001,{ }^{\mathrm{b}} p$-value $<0,05$. \\
\end{tabular}

Selanjutnya, uji reliabilitas dilakukan dengan menggunakan nilai composite reliability dan cronbach alpha dengan menggunakan nilai acuan lebih besar atau sama dengan 0,7 (Sholihin dan Ratmono, 2013). Hasil pengujian menunjukkan bahwa semua variabel pada penelitian ini memiliki nilai composite reliabitly dan cronbach alpha diatas 0,7. Dengan begitu, semua variabel pada penelitian ini dapat dikatakan reliabel. Secara terperinci hasil pengujian tersebut dapat dilihat pada Tabel 2.

\section{Model Struktural}

Pengujian model struktural dilakukan untuk melihat kesesuaian model penelitian ini dengan data yang ada. Kesesuaian tersebut dilihat dari beberapa indeks di bawah ini.

Tabel 4. Indeks Kesesuaian Model

\begin{tabular}{ccc}
\hline Indeks & Nilai & Kriteria \\
\hline APC & 0.356 & $\mathrm{P}<0.001$ \\
ARS & 0.292 & $\mathrm{P}<0.001$ \\
AVIF & 1.417 & Ideally $<=3.3$ \\
\hline
\end{tabular}

Hasil pengujian menunjukan bahwa semua indeks memiliki nilai yang disyaratkan oleh masing-masing indeks yaitu nilai APC, ARS, dan AVIF. Masing-masing indeks mendapatkan nilai berturut-turut $0.356,0.292$ dan 1.417 . Uji koefisien determinasi $\left(\mathrm{R}^{2}\right)$ dilakukan untuk melihat seberapa besar variabel kemudahan penggunaan dan keamanan mempengaruhi niat penggunaan, dan seberapa besar variabel niat penggunaan mempengaruhi niat merekomendasikan layanan m-payment. Nilai $\mathrm{R}^{2}$ dalam penelitian ini ditemukan sebesar 0,52 dan 0,06 . Artinya, $52 \%$ varians dari niat penggunaan m-payment dapat dijelaskan oleh variabel kemudahan penggunaan dan keamanan. Sedangkan $6 \%$ varians dari niat merekomendasikan layanan m-payment. Oleh karena itu, dapat disimpulkan bahwa model struktural dalam penelitian ini dapat dikatakan telah memenuhi kriteria goodness of fit yang sangat baik.

Uji hipotesis dilakukan dengan melihat nilai koefisien jalur $(\beta)$ dan $p$-value dari setiap jalur yang telah dikembangkan berdasarkan teori dan hipotesis sebelumnya seperti yang terlihat pada Gambar 2.

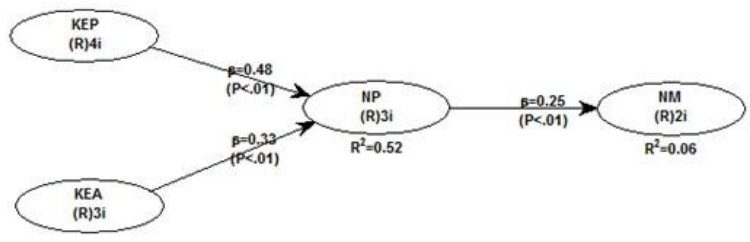

Gambar 3. Model, Hipotesis dan Hasil Penelitian

Hasil pengujian model struktural di atas menunjukkan bahwa koefisien jalur pada pengaruh kemudahan penggunaan dan keamanan terhadap niat penggunaan ditemukan signifikan secara statistik pada tingkat $1 \%(\beta=$ $0,48, p$-value $<0,01)$ dan $(\beta=0,33 p$-value < $0,01)$. Koefisien jalur pada pengaruh niat penggunaan terhadap niat merekomendasikan ditemukan juga signifikan secara statistik pada tingkat $1 \%(\beta=0,25, p$-value $<0,01)$.

\section{Pembahasan}

Hasil penelitian ini menunjukkan bahwa kemudahan penggunaan memiliki pengaruh yang positif dan signifikan terhadap niat penggunaan m-payment di pengguna di kota Serang. Hal ini terlihat dari hasil statistik yang menunjukkan bahwa nilai koefisien dan $p$-value jalur yang telah diuji yaitu $\beta=$ $0,48, p$-value $<0,01$, sehingga hipotesis 1 didukung. Kemudahan penggunaan memiliki pengaruh yang kuat untuk mendorong niat penggunaan m-payment. Kemudahan tersebut terlihat dari kejelasan dan kemudahan dalam memahami penggunaan m-payment, tahapan penggunaanya yang tidak rumit dan terbilang mudah, sehingga responden merasa bahwa beberapa kemudahan tersebut memiliki pengaruh yang dapat mendorong seseorang untuk memiliki niat dalam menggunakan layanan m-payment secara terus-menerus. Hasil penelitian ini sejalan dengan penelitian yang dilakukan Ikhsan dan Sunaryo (2020), Johnson et al., (2018) dan Phonthanukitithaworn et al., (2016) yang menemukan bahwa kemudahan 
penggunan memberikan pengaruh positif terhadap niat penggunaan suatu teknologi khususnya teknologi m-payment.

Hasil penelitian ini menunjukkan bahwa keamanan memiliki pengaruh yang positif dan signifikan terhadap niat penggunaan $m$ payment di pengguna di kota Serang. Hal ini terlihat dari hasil statistik yang menunjukkan bahwa nilai koefisien dan $p$-value jalur yang telah diuji yaitu $\beta=0,33, p$-value $<0,01$, sehingga hipotesis 2 didukung. Keamanan memiliki pengaruh yang kuat untuk mendorong niat penggunaan m-payment. Keamanan tersebut terlihat dari langkahlangkah untuk melindungi penggunanya seperti adanya password untuk masuk dan setiap kali melakukan transaksi, mampu melakukan verifikasi pengguna yang sah dan informasi pengguna selalu dirahasiakan, sehingga responden merasa bahwa $m$ payment telah memberikan keamanan bagi pengguna selama dan saat transaksi keuangan berlangsung. Hasil penelitian ini sejalan dengan penelitian yang dilakukan Oliveira et al., (2016), Johnson et al., (2018), Liébana-Cabanillas et al., (2017a) dan Liébana-Cabanillas et al., (2018) yang menemukan bahwa keamanan memberikan pengaruh positif terhadap niat penggunaan suatu teknologi m-payment.

Hasil penelitian ini menunjukkan bahwa niat penggunaan memiliki pengaruh yang positif dan signifikan terhadap niat merekomendasikan m-payment di pengguna di kota Serang. Hal ini terlihat dari hasil statistik yang menunjukkan bahwa nilai koefisien dan $p$-value jalur yang telah diuji yaitu $\beta=0,25, p$-value $<0,01$, sehingga hipotesis 3 didukung. Niat seseorang dalam menggunakan sistem m-payment memainkan peran penting bagi mereka untuk merekomendasikan sistem terebut kepada orang lain. Niat untuk merekomendasikan tersebut muncul karena mereka memiliki pengalaman yang baik dalam menggunakan sistem m-payment, sehingga merasa perlu untuk membagikan pengalaman tersebut kepada orang lain
(Oliveira et al., 2016). Hasil penelitian ini sejalan dengan penelitian yang dilakukan Oliveira et al., (2016) dan Miltgen et al., (2013) yang menemukan bahwa niat penggunaan memberikan pengaruh positif terhadap niat merekomendasikan suatu teknologi khususnya teknologi m-payment.

\section{KESIMPULAN}

Kemudahan penggunaan dan keamanan memiliki pengaruh positif dan signifikan terhadap niat penggunaan $m$ payment, dan niat penggunaan memiliki pengaruh positif dan signifikan terhadap niat merekomendasikan m-payment di Kota Serang. Untuk meningkatkan niat penggunaan m-payment di Kota Serang penyedia layanan m-payment perlu mempertimbangkan dan menyediakan kemudahan penggunaan m-payment dalam melakukan transaksi. Selain itu, penyedia layanan m-payment juga perlu memberikan dan memastikan bahwa sistem tersebut aman baik tentang informasi pribadi ataupun selama transaksi keuangan berlangsung. Meningkatnya niat untuk menggunakan $m$ payment yang ditimbulkan dari pengalaman baik atas kemudahan penggunaan serta keamanan sistem tersebut akan mendorong konsumen untuk merekomendasikan layanan tersebut kepada orang lain. Penelitian ini memiliki keterbatasan karena hanya dilakukan di kota Serang, sehingga penelitian selanjutnya diharapkan dapat diperluas dengan menambahkan responden dari beberapa kota lainnya di Pulau Jawa seperti Jakarta dan Surabaya. Dengan begitu, diharapkan dapat memberikan gambaran yang lebih komprehensif tentang penggunaan m-payment dari masyarakat Indonesia.

\section{PERNYATAAN}

Penelitian ini dibiayai oleh Kementrian Pendidikan, Kebudayaan, Riset dan Teknologi sesuai dengan Kontrak Penelitian Tahun Anggaran 2021 dengan no. Kontrak 


\section{EKOMBIS Sains}

065/SP2H/LT/DPRM/2021 tanggal 18

Maret 2021.

\section{DAFTAR PUSTAKA}

APJII. (2017). Infografis: penetrasi \& perilaku pengguna internet Indonesia survey 2017.

APJII. (2018). Infografis: penetrasi \& perilaku pengguna internet Indonesia survey 2018.

Aslam, W., Ham, M., \& Arif, I. (2017). Consumer Behavioral Intentions towards Mobile Payment Services: An Empirical Analysis in Pakistan Market. Tržište, 29 (2), 161-176.

Bailey, A.A., Pentina, I., Mishra, A.S., dan Mimoun, M.S.B. (2017). mobile payments adoptions by US consumers: an extended TAM. International Journal of Retail \& Distribution Management, 45(6), 1-17.

Chaouali, W., Ben Yahia, I., dan Souiden, N. (2016). The interplay of counterconformity motivation, social influence, and trust in customers' intention to adopt Internet banking services: The case of an emerging country. Journal of Retailing and Consumer Services, 28, 209-218.

Davis, F.D. (1989). Perceived usefulness, perceived ease of use, and user acceptance of information technology. MIS Quarterly, 13, 319-340.

Davis, F.D., Bagozzi, R.P., \& Warshaw, P.R. (1989). User acceptance of computer technology: a comparison of two theoretical models. Management Science, 35, 982-1003.

Ghozali, I. 2018. Aplikasi Analisis Multivariate Dengan Program IBM Spss 25. Semarang: Badan Penerbit Universitas Diponegoro.
Hsu, C. L., \& Lin, J. C. C. (2016). Effect of perceived value and social influences on mobile app stickiness and in-app purchase intention. Technological Forecasting and Social Change, 108, 42-53.

Ikhsan, K., dan Sunaryo, D. (2020). Technology acceptance model, Social Influence And Perceived Risk In Using Mobile Application: Empirical Evidence In Online Transportation In Indonesia. Jurnal Dinamika Manajemen, 11(2), 127-138.

Jogiyanto. (2007). Sistem Informasi Keperilakuan. Edisi Revisi. Yogyakarta: AndiOffset.

Johnson, V.L., Kiser, A., Washington, R., dan Torres, R. (2018). Limitations to the Rapid Adoption of M-payment Services: Understanding the Impact of Privacy Risk on M-Payment Services. Computers in Human Behavior, 79, 111-122.

Liébana-Cabanillas, F., Luna, I.R.D., dan Montoro-Ríos, F. (2017a). Intention to use new mobile payment systems: a comparative analysis of SMS and NFC payments. Conomic ResearchEkonomska Istraživanja, 30(1), 892910.

Liébana-Cabanillas, F., Leiva, F.M., dan Fernández, J.S. (2017b). Chapter 6: Examining Merchants' Refusal to Adopt Mobile Payment Systems in Spain.

Liébana-Cabanillas, F., Marinkovic, V., Luna, I.R.D, dan Kalinic, Z. (2018). Predicting the determinants of mobile payment acceptance: A hybrid SEMneural network approach. Technological Forecasting \& Social Change, 129, 117-130.

Mallat, N., Rossi, M., Tuunainen, V. K., \& Oorni, A. (2009). The impact of use context on mobile services 


\section{EKOMBIS Sains}

acceptance: The case of mobile ticketing. Information \& Management, 46 (3), 190-195.

MDI Ventures dan Mandiri Sekuritas Research. (2019). Mobile payment in Indonesia: race to big data domination.

Metemba, E.D., dan Li, G. (2018). Consumers' willingness to adopt and use WeChat wallet: An empirical study in South Africa. Technology in Society, 53, 55-68.

Miltgen, C. L., Popovic, A., dan Oliveira, T. (2013). Determinants of end-user acceptance of biometrics: integrating the "Big 3" of technology acceptance with privacy context. Decision Support Systems, 56, 103-114.

Noor, J. 2017. Metodologi penelitian: skripsi, tesis, disertasi dan karya ilmiah, edisi pertama. Jakarta: Kencana.

Oliveira, T., Thomas, M., Baptista, G., dan Campos, F. (2016). Mobile payment: Understanding the determinants of customer adoption and intention to recommend the technology. Computers in Human Behavior, 61, 404-414.

Phonthanukitithaworn, C., Sellitto, C., dan Fong, M.W.L. (2016). An investigation of mobile payment (mpayment) services in Thailand. AsiaPacific Journal of Business Administration, 8 (1), 37-54.

Tsiakis, T., dan Sthephanides, G. (2005). The concept of security and trust in electronic payments. Computers and Security, 24, 10-15.

Zhou, T. (2011). The effect of initial trust on user adoption of mobile payment. Information Development, 27(4), 290300.

Zhu, D., Lin, T. C-T., dan Hsu, Y-C. (2012). Using the technology acceptance model to evaluate user attitude and intention of use for online games. Total Quality Management \& business excellence, 23(7-8), 965-980. 